\title{
Do Fairness Perceptions Matter in Tax Compliance? The Effect of Procedural $\times$ Distributive Justice Interaction on Intention to Pay Taxes
}

\author{
Lemessa Bayissa GOBENA \\ College of Finance, Management and Development, Ethiopian Civil Service University, Ethiopia
}

\begin{abstract}
This study examined the interactive effect of procedural and distributive justice on intention to pay taxes. Data for the study were gathered through a cross-sectional survey administrated to category $\mathrm{C}$ taxpayers in Addis Ababa and some surrounding Oromia zones. A hierarchical multiple regression and PROCESS macro regression analyses results revealed that taxpayers' intention to voluntarily comply with tax obligations depends on their perceptions of distributive justice and their emotional attachment with the tax authorities. Moreover, procedural justice was found to be a moderator of the effect of distributive justice on intention to voluntarily pay taxes.
\end{abstract}

Keywords: Procedural justice, distributive justice, intention to pay taxes voluntarily, interactive effect.

DOI: $10.7176 / \mathrm{RJFA} / 12-3-04$

Publication date: February $28^{\text {th }} 2021$

\section{Introduction}

Taxation is important to governments not only because of the revenue they generate from it but also because of its ability to uphold the bond between the government and its citizenry (e.g., Prichard, 2010; Traxler, 2009; Wahl, Muehlbacher, \& Erich, 2010). Taxation upholds the bond between the government and its citizenry as it establishes a sense of contract between the two (Fjeldstad and Semboja, 2001). In this contract, the government takes the responsibility to pool public resources for provision of common goods and services and taxpayer citizens consider tax payment as civic duty when the government is accountable to its citizens (see Alm et al., 1993; Fjeldstad and Semboja, 2001; Torgler, 2003). In most countries in Africa, among which Ethiopia is one, nevertheless taxation seems to miss the second attribute, namely upholding the connection between the government and the citizenry (see Fjeldstad, Schulz-Herzenberg, \& Sjursen, 2012; Fjeldstad \& Therkildsen, 2008; Gobena \& Van Dijke, 2017). This is because African governments are less accountable to their citizens and care more about the money they generate via taxation even at the expense of any form of hostility it could cause between them and their citizens (see Fjeldstad, 2001; Tanzi, 2006; Gervasoni, 2006; OECD, 2008; Bekana et al., 2014; Gobena \& van Dijke, 2016, 2017).

As a reflection of the loose bond between taxpayer citizens and the government, in the year 2017, lower level taxpayers (i.e., category "C" taxpayers) in Ethiopia, whose tax liability is determined based on standard assessments, took their grievances to tax and other concerned officials via public demonstrations. Their complaints were aired on mainstream media as perceived unfair assessments by tax officials of their tax liabilities. Fairness in the standard assessments primarily concerns two elements of justice - procedural and distributive justice (Palil, 2010; Saad, 2011). Perceived procedural fairness (i.e., procedural justice) in the tax compliance context refers to the fairness in decision-making processes that pertain to determination of tax liability, consideration of taxpayers' concerns and voices, suppression of bias towards any group and one's self interest (Farrar, 2015; Gobena \& van Dijke, 2016, 2017). To the contrary, perceived procedural unfairness means that the taxpayers view the decisionmaking processes the tax authorities pursue as unfair impairing one or more attributes of procedural fairness mentioned above.

Distributive justice in the tax compliance arena, on the other hand, refers to the perceived fairness of distribution of tax burdens and tax-funded benefits (Verboon \& van Dijke, 2007; Farrar \& Thorne, 2012). Studies on tax compliance to date attempted to show the main effects of procedural and distributive justice, often separately (see Wenzel, 2002, 2003, Verboon \& van Dijke, 2007). In the current study, the aim is to explore the interactive effect of the two elements of justice, namely procedural and distributive justice. Of course, van Dijke, Gobena \& Verboon (2019) showed that procedural by distributive justice interaction affects voluntary tax compliance, but only when legitimate power of the tax authority is high (vs. low). In this study, the use of authority power as a boundary conditioned is omitted to examine the interactive role the two components of justice on intention to pay taxes. The omission of the boundary condition serves as a stricter approach to exploring the exclusive effect of the two elements of justice in its own right in tax compliance context as recommended in organizational behavior studies (for review, see Brockner and Wiesenfeld, 1996). 


\section{Related Literature and Hypothesis}

\subsection{Distributive Justice, Procedural Justice and Voluntary Tax Compliance}

Distributive justice theory (Rawls, 1971) calls for a socially just allocation of goods and services in a society. In other words, it is about the fair, just or equitable distribution of benefits and burdens. These benefits and burdens cover all dimensions of social encounters and comprise income, economic wealth, political power, taxation, work obligations, education, shelter, healthcare, military service, community involvement and religious activities. In contemporary political philosophy, distributive justice is interpreted in broad terms and seen as a footing for policy development and analysis. For Rawls (1971), for instance, "Justice is the first virtue of social institutions." Of course, if people do not think that they are getting their fair share of what they expect to get, they will seek first to gain what they believe they deserve. In doing so, they may seek other forms of justice (Saad, 2011).

Distributive Justice Theory is not only concerned with fairness of distribution of benefits but also with the fairness of allocation of punishments, known as retributive fairness (Cook and Hegtvedt, 1983). Retributive fairness posits that a social system is considered fair when the penalty imposed is commensurate with the crime committed. Similarly, the social system is perceived as fair if the compensation received is proportional to the sacrifice incurred in the social system.

Empirical studies show an expressed concern for helping those in need and demonstrate a willingness of people to sacrifice materially to realize that goal (Wenzel, 2003; Verboon \& Van Dijke, 2007). They suggest that just allocations provide for basic needs equally across individuals. Specifically, the evidence suggests that need is one of several principles and that it tends to dominate when basic needs are endangered. A review of literature on distributive preferences hints that people care about the happiness or subjective value resulting from allocations (Cohen-Charash \& Spector, 2001; Saad, 2011). There is also qualified support for the Pareto and Compensation Principles, even if this support is markedly compromised when they conflict with other distributive goals. Nonexistence of envy inherent in distributive justice, for example, is accompanied by a concern for efficiency.

Enhancing perceptions of distributive justice boosts authorities' performance (Cohen-Charash \& Spector, 2001; Karriker \& Williams, 2009). This holds because decision recipients react more positively when decision outcomes are perceived as fair, rather than unfair (e.g., Van Dijke, Gobena and Verboo, 2019; Bianchi et al., 2015; Brockner, 2002; Leventhal, 1976). In the same vein, the tax compliance literature has shown that taxpayers voluntarily comply with tax laws when they perceive the distribution of tax burdens and benefits across individuals, groups, and the society as a whole as fair rather than when the distributions are unfair (e.g., Van Dijke, Gobena and Verboo, 2019; Saad, 2011; Verboon and Goslinga, 2009; Wenzel, 2002, 2003). A relevant inherent factor embedded in distributive justice of a tax system is the equitability of the exchange between taxpayer citizens and the government (Alm, Jackson, \& McKee, 1993; Rablen, 2010). Exchange equity refers to the notion that over the long run, taxpayers receive appropriate value for the taxes they pay (see Bird \&Zolt, 2008; Tanzi, 2006). In fact, in less democratic nations throughout Africa, Asia, and Latin America, taxpayers get less information in regard to how their governments spend the tax money while it is unquestionable that exchange equity fosters voluntary tax compliance (Fjeldstad \& Therkildsen, 2008; Leder, Mannetti, Hölzl, \& Kirchler, 2010; Moser, Evans, \& Kim, 1995).

Nonetheless, scholars have realized that fair distribution of outcomes (i.e., distributive justice) and fair exchange equity are insufficient to explain the response of members of social collectives to the collective authorities (Wenzel, 2003; Van Dijke et al., 2019). Specifically, it is also equally important to consider the perceived fairness of the decision-making procedures that authorities apply in arriving at the distributive decisions (see Doyle et al., 2009; Seidikides et al., 2010; Farrar, 2015). Members of a social collective value fairness of authorities in enacting rules, resolving disputes, and allocating resources (i.e., procedural justice; Leventhal, 1980; Thibaut and Walker, 1975). Fairness perception is shaped by a number of decision-makers' actions. Some of these actions include consistent application of the procedures across time, absence of decision-makers' self-interest in the process, basing decisions on accurate information, and allowing decision recipients to voice their opinions in the decision-making processes (Leventhal, 1980; Thibaut and Walker, 1975; van den Bos et al., 1996; Saad, 2011). Research shows that authorities' procedural justice begets positive attitudes and cooperative behaviors from followers (Thibaut and Walker, 1975; Tyler and Blader, 2000; Lind, 2001; Murphy, 2003). Instances of such effects of procedural justice include rule-following (e.g., Tyler, 2009), and public support for police (e.g., Jason and Tyler, 2003). In the tax compliance literature also, studies show that procedural justice stimulates voluntary compliance with tax laws (Van Dijke, Gobena and Verboon, 2019; Farrar, 2015; Hartner et al., 2008; Murphy and Tyler, 2008).

Furthermore, scholars have recognized that it is more important to study distributive justice and procedural justice not in isolation, but rather as interactive predictors of responses to authorities and the system they represent (e.g., Bianchi et al., 2015; Brockner and Wiesenfeld, 1996; De Cremer, 2005). The Procedural Justice $\times$ Distributive Justice interaction has been studied from two perspectives. Some researchers showed that procedural justice gains influence on peoples' reactions to a decision when distributive justice is low (vs. high; e.g., Shapiro, 1991). Others showed that distributive justice becomes more relevant in stimulating individuals' reactions to authorities' decisions when procedural justice is low (vs. high; see Brockner et al., 1994 for review). However, 
both forms of the Procedural Justice $\times$ Distributive Justice interaction lead to high procedural justice or high distributive being sufficient to lead to positive responses to the authority in the form of will to defer to the authority's decisions. In other words, negative responses appear only when procedural justice and distributive justice are both low.

Various theories explain the effect of the Procedural Justice $\times$ Distributive Justice interaction on responses to authorities and the collective they represent. More specifically, referent cognitions theory (Folger, 1987), the instrumental model of justice (Thibaut and Walker, 1975), and the group value model (Lind and Tyler, 1988) offer explanations as to why the Procedural Justice $\times$ Distributive Justice interaction predicts cooperative responses of individuals to collective authorities. Brockner and Wiesenfeld (1996) and De Cremer et al. (2010) note that the explanations by the aforementioned theories can be understood as emphasizing a sense-making process. The argument of the sense-making process is that individuals interpret and assign meaning to events and encounters, mainly in response to negative, unexpected, or ambiguous circumstances (see Jones and Skarlicki, 2013; Weick, 1995). Before they assign meaning, people consider other aspects of their encounters. For example, unfair (vs. fair) outcomes are perceived as negative; this makes people want to make sense of their surroundings by asking the following question: "Can I understand something about why this negative experience materialized and how bad the future will look like?" Procedural justice offers a partial answer to this question, in the sense that low procedural justice conveys information that unfair outcomes are results of an unfair decision-making procedure and are thus more likely to continue into the future. Fair procedures, on the other hand, communicate that the unfair outcomes result from chance, or at least from a less stable factor, and are therefore less likely to continue into the future (Seidikides, De Cremer, Hart \& Brebels, 2010). This leads to a relatively strong positive effect of distributive justice on responses to authorities when procedural justice is low (vs. high). The above arguments culminate in the following hypothesis.

High procedural justice leads to high intention of taxpayers to voluntarily comply with taxation when distributive justice is low (vs. high).

This study explores the interactive effect of the two justice components on intention to voluntarily comply with taxation, controlling for some demographic variables and trust in the tax authority, as shown in figure 1 below.

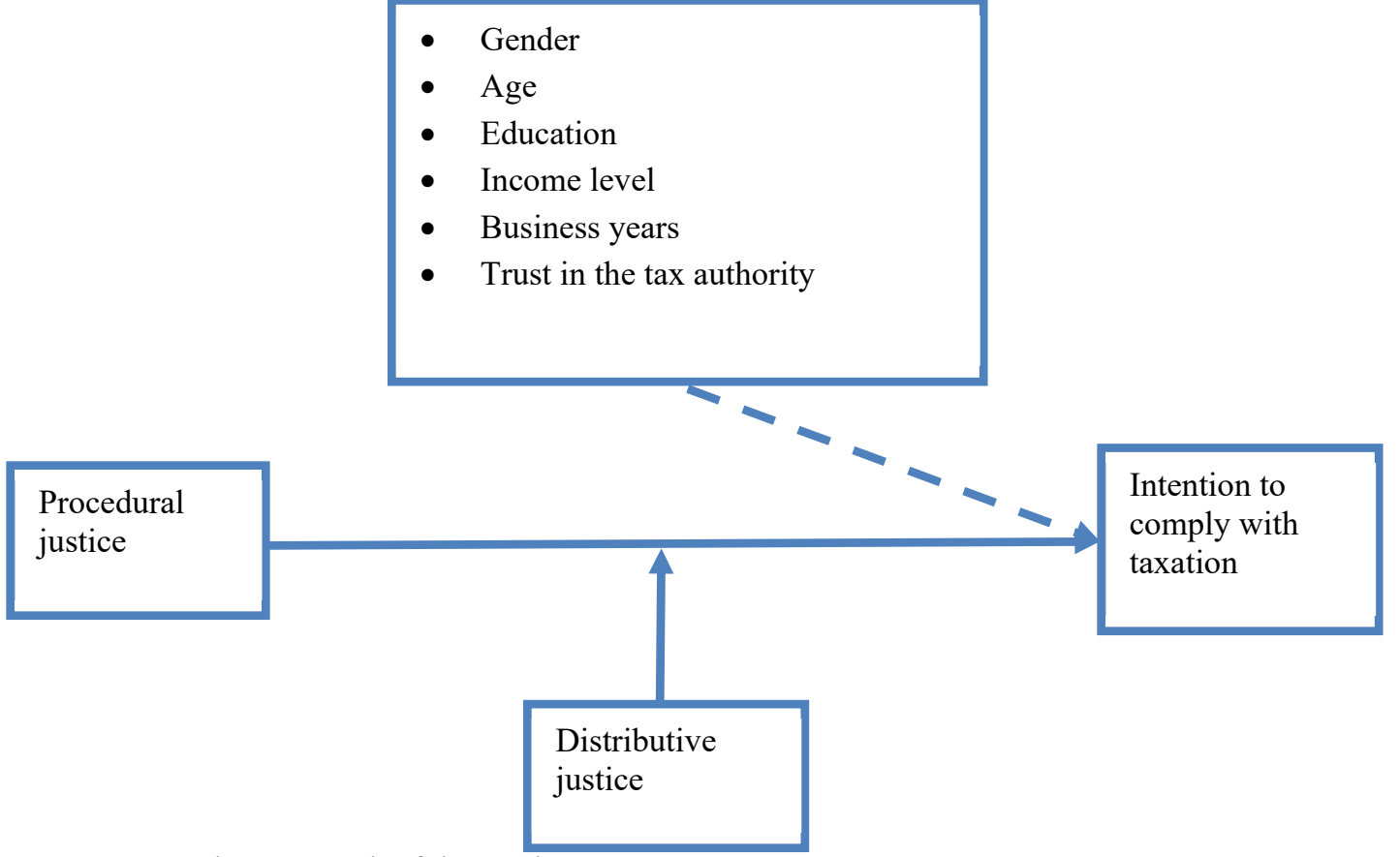

Figure 1: Conceptual Framework of the Study

\section{Method}

\subsection{Respondents}

Data were gathered from a sample of 761 category " $C$ " taxpayers (i.e., taxpayers whose tax liabilities are determined on the basis of standard assessments) in Addis Ababa and surrounding Oromia zones. Given that the tax authority does not allow any third party to access taxpayers' information and that it is impossible obtain the number of Category "C" taxpayers, it was not possible to use probability sampling techniques. Consequently, a convenient sample of 812 taxpayers (412 from Addis Ababa City administration and 400 from Oromia zones around Addis Ababa) were drawn to fill a self-administered questionnaire. In respect of the risk of nonrepresentativeness of the sample, the large sample size and the fact that behavioral studies often utilize convenience 
sampling without serious threat to their conclusions (see Leary, 2012) guarantee the validity of the results drawn from this study.

The study sample consisted of 716 category "C" taxpayers in the Ethiopian capital, Addis Ababa and Oromia zones surrounding Addis Ababa, namely Lege Tafo, Sululta, and Burayu. A questionnaire prepared in English and translated into Amharic language was administered to the respondents. Of the respondents, $53.5 \%$ were male, $37.8 \%$ were female, and $8.8 \%$ did not indicate their gender. Respondents were between 20 and 60 years of age $\left(M_{\text {age }}=39.8, S D_{\text {age }}=8.23\right)$. With regard to the highest level of education, $23.5 \%$ had completed elementary education only, $21 \%$ had completed high school education, $21.8 \%$ had a 2 -year college diploma, $13.3 \%$ had a bachelor's degree, $2 \%$ had completed a master's degree and above, and 18.4\% did not indicate their highest level of education. With respect to their annual earnings, $42.6 \%$ of the respondents reported that they had annual earnings of 20,000-40,000 Ethiopian Birr, 12.8\% had earned 40,000-60,000 Birr, 9.7\% had earned 60,000-80,000 Birr, 7\% had earned 80,000-100,000 Birr, 8.7\% had earned 100,000-120,000 Birr, 6.4\% had earned more than 120,000 Birr, and 12.8\% did not indicate their annual earnings. Among the respondents, $24.8 \%$ reported that they had less than 2 years of experience with the tax authority, $27.8 \%$ had 2-6 years, $20 \%$ had $6-10$ years, $12.1 \%$ had $10-20$ years, $9.1 \%$ had more than 20 years of experience, and $6.2 \%$ did not disclose their years of experience with the tax authority. The demographic control variables were coded as: (a) income range of respondents, $1=20,000-40,000$ Birr, $2=40,000$ 60,000 Birr, $3=60,000-80,000$ Birr, $4=80,000-100,00$ Birr, $5=100,000-120,000$ Birr, and $6=$ more than 120,000 Birr; years of experience with the tax authority, $1=$ less than 2 years, $2=2-6$ years, $3=6-10$ years, $4=10-20$ years, and $5=$ more than 20 years; highest level of education attained, $1=$ completed elementary school, $2=$ completed high school, $3=$ completed college diploma, $4=$ completed first degree, $5=$ completed master's degree, and $6=$ completed a $\mathrm{PhD}$.

\subsection{Procedure}

The study employed a printed questionnaire and unstructured interview to collect data. The data were collected the over a period of three months, January-March, 2018. A total of 812 questionnaires were distributed to category " $\mathrm{C}$ " taxpayers in Addis Ababa and three Oromia zones surrounding Addis Ababa. Accompanying the questionnaire was a cover letter that explains the intent of the study and guarantees strict confidentiality of responses. Seven hundred and ninety-six questionnaires were returned. Of these, thirty-five respondents skipped a significant number of questions and were therefore removed from the dataset. Accordingly, a total of 761 usable questionnaires were included in the analysis.

\subsection{Measures}

Procedural justice was measured with a 7-item scale developed and validated by Colquitt (2001). The study preferred to use this scale over scales that were used before in the tax compliance literature because those other scales include items that do not accurately refer to aspects of decision-making procedures, and often overlap with other constructs. For instance, Murphy's (2004) measure of procedural justice of the tax authority contains items that measure trust. An example item that overlaps with trust is "The tax office treats people as if they can be trusted to do the right thing." The Colquitt (2001) measure, however, is exclusively based on Leventhal's (1980) and Thibaut \& Walker's (1975) concept of procedural justice and measures the most common procedural justice criteria: voice, bias suppression, accuracy, consistency, and adherence to norm. Therefore, this measure is an improvement over existing procedural justice measures in the tax compliance literature. The Colquitt (2001) items were slightly adapted to fit the context of procedural justice of the tax authority. Item examples (preceded by the stem "The following items refer to the procedures used to arrive at tax-related decisions.") are "I have been able to express my views and feelings during those procedures" and "Those procedures have been free of bias" $(1=$ strongly disagree, 7 = strongly agree). The items were averaged into a procedural justice scale. The complete adapted scale is found in Appendix A on page 23.

Distributive justice of the tax authority was measured with a 5-item scale from Verboon and van Dijke (2007) that measures both taxpayers' horizontal and vertical equities in addition to exchange equity with the government. Item examples are "The use I make of all kinds of social services reflects in a proper way the taxes I pay" and "Regarding social services I get little return for my tax money" (reverse coded) $(1=$ completely disagree, $7=$ completely agree). We averaged these items into a distributive justice scale.

Cognition- as well as affect-based trust were included as control variables. Cognition-based trust was measured with the 6-item scale developed by McAllister (1995). The scale items were slightly adapted to fit the context of trust in the tax authority. Item examples are "The tax officials approach their job with professionalism and dedication" and "Given these officials' track record, I see no reason to doubt their competence and preparation for their job" ( 1 = completely disagree, 7 = completely agree $)$. We averaged the items into one scale. We measured affect-based trust with the 5-item scale from McAllister (1995). We slightly adapted the items to fit the context of trust in the tax authority. Item examples are "The tax officials and I have a sharing relationship; we can both freely share our ideas, feelings, and hopes" and "I can talk freely to these officials about difficulties I am having regarding 
tax and know that they will want to listen" ( 1 = completely disagree, $5=$ completely agree). We averaged the items into one scale.

Intention to voluntarily pay taxes was measured with the 10-item scale ${ }^{1}$ from Kirchler and Wahl (2010). Item examples (preceded by the stem "When I pay my taxes as required by the Ethiopian tax laws and regulations, I do so...") are "...because to me it's obvious that this is what you do" and "...to support the state and other citizens" $(1=$ completely disagree, $7=$ completely agree $)$. We averaged the items to create a voluntary tax compliance index.

\section{Results and Discussions}

\subsection{Descriptive Statistics}

Table 1 below shows that all the variables of interest in this study (i.e. distributive justice, procedural justice, affect-based trust, and cognition-based trust) are associated with respondents' intention to pay taxes voluntarily with procedural justice only moderately related to it. These associations are in line with prior findings (see, for instance, Wenzel, 2002, 2003; Gobena and van Dijke, 2017 for association of procedural and distributive justice with voluntary tax compliance, and Murphy, 2004; Gobena and van Dijke, 2016, 2017 for correlation of trust with voluntary tax compliance). Of the demographic control variables, only gender is significantly related with intention to pay taxes voluntarily, female taxpayers exhibiting more voluntarism compared to their male counterparts. This is in line with a prior finding documented by Wenzel (2002).

Table 1

Study Variables' Means, Standard Deviations, Correlations, and Reliabilities

$\begin{array}{llllllllllll}\begin{array}{l}\text { Mean } \\ \text { (SD) }\end{array} & 1 & 2 & 3 & 4 & 5 & 6 & 8 & 9 & 10 & 11 & 12\end{array}$

1. Gender

2. Age Range 1.99

(1.07) $\quad .03$

3. Education $2.38 \quad-.01 \quad .03$

4. Annual $2.38 \quad-.04 \quad .54 * * \quad .14 * *$

Income (1.69)

5. Years of $\quad \begin{array}{lllll}2.50 & -.03 & .56^{* *} & .03 & .50 * *\end{array}$

Experience (1.28)

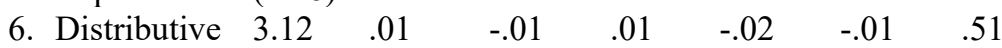
Justice $\quad(0.80)$

$\begin{array}{lllllllll}\text { 7. Procedural } & 2.44 & .06 & -.02 & -.03 & -.04 & .13 * * & .30 * * & .81\end{array}$ Justice $\quad(0.91)$

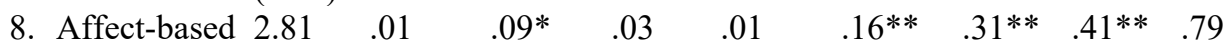
Trust (1.11)

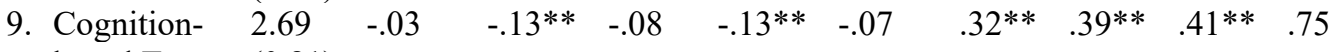
based Trust $(0.81)$

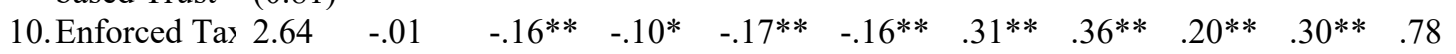
Compliance $(0.87)$

$\begin{array}{lllllllllllll}\text { 11. Voluntary } & 3.88 & -.12 * * & -.05 & .05 & .01 & .02 & .22 * * & .09 * & .23 * * & .11 * * & .10 * * & .77\end{array}$ Tax $\quad(0.68)$

$\mathrm{N}=796$

Reliabilities (Cronbach's $\alpha$ coefficients) are on the main diagonal for multi-item scales.

*: $p<.05$.

** $: p<.01$.

\subsection{Regression Analyses}

Two regression analyses were conducted in order to examine the main and interactive effects of the variables considered as determinants of category " $C$ " taxpayers' intention to pay their taxes voluntarily. The first is a multiple regression in which all the independent variables were included in the analysis and regressed on the intention of the responded taxpayers to voluntarily comply with their tax obligations. Table 2 below depicts the results of the regression analysis.

\footnotetext{
${ }^{1}$ Using the abridged 5-item scales for intention to voluntarily comply with tax authorities (Kirchler \& Wahl, 2010) revealed results that were essentially the same to the results presented in this chapter.
} 
Table 2. Hierarchical Multiple Regression Output Consisting of All the Study Variables

\begin{tabular}{|c|c|c|c|c|}
\hline \multirow{2}{*}{ Model } & \multicolumn{4}{|c|}{ Standardized Coefficients } \\
\hline & & Beta & $\mathrm{t}$ & Sig. \\
\hline \multirow{6}{*}{$\begin{array}{c}\text { Step 1 } \\
\mathrm{R}^{2}=.71\end{array}$} & & & 31.41 & $.00 * *$ \\
\hline & Gender & -.10 & -2.25 & $.03 *$ \\
\hline & Education & .05 & 1.18 & .24 \\
\hline & Age & -.15 & -2.56 & $.01 * *$ \\
\hline & Income & .03 & .53 & .60 \\
\hline & Business Years & .12 & 2.17 & $.03 *$ \\
\hline \multirow{10}{*}{$\begin{array}{c}\text { Step } 2 \\
\mathrm{R}^{2}=.74\end{array}$} & & & 32.10 & $.00 * *$ \\
\hline & Gender & -.09 & -2.08 & $.04 *$ \\
\hline & Education & .01 & .27 & .79 \\
\hline & Age & -.13 & -2.27 & $.02 *$ \\
\hline & Income & .05 & 1.03 & .31 \\
\hline & Business Years & .11 & 1.95 & .05 \\
\hline & Distributive Justice & .11 & 2.21 & $.03 *$ \\
\hline & Procedural Justice & -.03 & -.57 & .57 \\
\hline & Affect-based Trust & .11 & 2.20 & $.03 *$ \\
\hline & Cognition-based Trust & .01 & .08 & .94 \\
\hline
\end{tabular}

*: $p<.05$.

** $p<.01$

As table 2 shows, gender, age, and years of business experience, considered separately, significantly predicted intent to pay tax voluntarily. Of course, while gender and age negatively affected intent to voluntarily pay tax, years of business experience positively predicted it. The negative coefficients of gender and age mean that female respondents reported to have greater intention to voluntarily pay their taxes than their male counterparts and older respondents have lesser intention to voluntarily pay their taxes than their younger counterparts. The positive coefficient of years of business experience means that the longer a respondent was in business, the more $s /$ he intended to voluntarily pay their taxes. Contrary to the anecdotal claim that the taxpayers complain about their assessed tax because it is beyond what they can afford to pay, the income of the taxpayers did not significantly predict their intention to voluntarily pay tax. Of the variables of interest, distributive justice and affect-based trust significantly predicted the intention to pay taxes voluntarily positively.

The second one was regression with PROCESS macro (Hayes, 2013; model 1) which was meant to examine the interactive role of procedural and distributive justice on the taxpayers' intention to voluntarily pay their taxes. Table 3 depicts the interactive effect of the two elements of justice on intention to pay taxes voluntarily. Table 3. The Effect of Procedural $\times$ Distributive Justice Interaction on Intention to Voluntarily Pay Taxes Dependent Variable Model

\begin{tabular}{lccc}
\hline & \multicolumn{3}{c}{ Outcome Variable: Intention to Voluntarily Pay Taxes } \\
\hline & $\mathrm{B}(\mathrm{SE})$ & $\mathrm{t}$ & $\mathrm{p}$ \\
Distributive Justice & $.14(.02)$ & 6.02 & .00 \\
Procedural Justice & $.03(.03)$ & 1.32 & .19 \\
Distributive Justice $\times$ Procedural Justice & $-.06(.02)$ & -2.78 & .01 \\
\hline Conditional indirect effect at specific levels of the moderator & & LL 95\% CI & UL 95\% CI \\
\hline Moderator: Distributive Justice & Indirect effect & & \\
\hline & .09 & .02 & .17 \\
\hline & .03 & -.02 & .08 \\
.00 (0 SD from the mean) & -.02 & -.08 & .03 \\
.99 (+1 SD from the mean) & & & \\
\hline
\end{tabular}

Table 3 shows that while distributive justice of the tax authority was sufficient to stimulate the intention to voluntarily pay taxes in its own right, the main effect of procedural justice did not predict the intention to voluntarily pay taxes. The interactive effect of procedural and distributive justice, which is of paramount interest to this study, negatively stimulated the taxpayers' intention to voluntarily pay taxes. The negative sign of the interaction effect means that procedural justice predicts intention to voluntarily pay taxes only when distributive justice of the tax authority is perceived to be low in the eyes of the taxpayers. When distributive justice is at its high, taxpayers do not need to look back on to the procedures (i.e., the decision-making processes) that led to the distribution of the favorable outcomes, namely tax burdens and tax-funded benefits. This finding is in line with the argument in the sense-making analysis of justice that people tend to look around for justifications of negative and unfavorable encounters to learn what the future holds (see Brockner \& Weidenfeld, 1996 for overview). This result concurs with many findings documented in organization behavior (e.g., Shapiro, 1991). 
The interactive effect of procedural and distributive justice on intention to pay taxes voluntarily is depicted in figure 2 below.

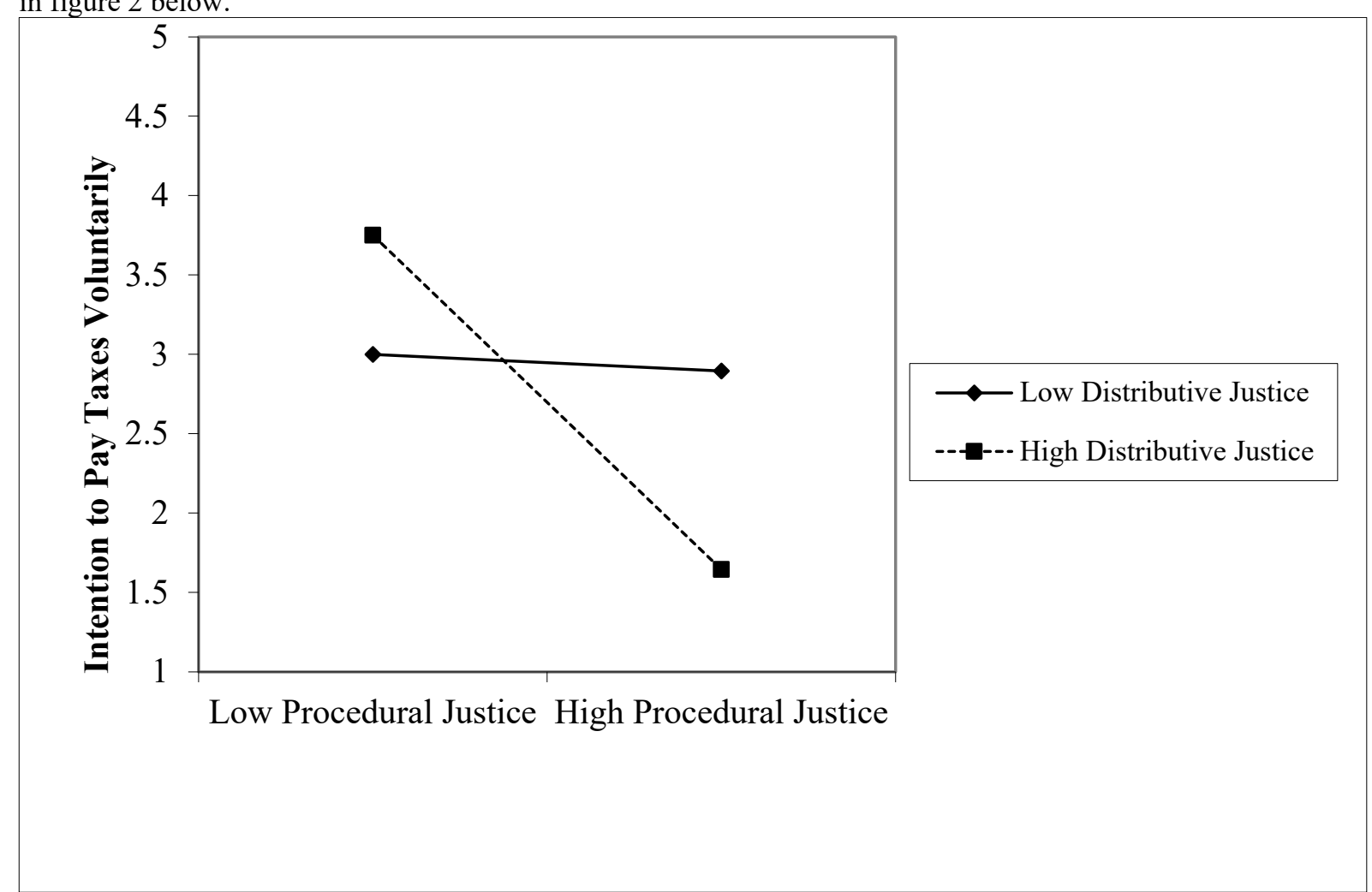

Figure 2. How Procedural x Distributive Justice Interaction Affects Intention to Pay Taxes Voluntarily

\subsection{Discussion}

Taxpayers' compliance with relevant tax laws often involves a fundamental social dilemma in which the taxpayers may decide to voluntarily cooperate with the tax authorities' decisions (for example, by paying their taxes) presuming that the tax money would be used by the government for mutual benefits with their fellow citizens. Alternatively, taxpayers may fear abuse of power by the tax authority (or the entire government) in which case the tax money would be used for non-productive government expenditure and may even be embezzled (see for instance, Alm, Jackson, \& McKee, 1993). The effect of this dilemma is heightened by citizens' lack of information on whether the tax authority (and the entire government system) can be trusted not abuse their power. In such circumstances, taxpayers often resort to procedural fairness information that they use a heuristic to guide their decisions to comply with or evade taxes (see Van Dijke and Verboon, 2010; Gobena and van Dijke, 2016, 2017). This study examined (1) the main effects of trust in the tax authority, procedural and distributive justice of the authority, and exchange equity of the authority and (2) the interactive role of procedural and distributive justice on intention to voluntarily pay taxes. The main effects of distributive justice and affect-based trust affected intention to voluntarily pay taxes. The interactive role of the tow justice components-procedural and distributive - also stimulated intention to voluntarily pay taxes. In the following sections, implications and limitations of the research are discussed.

\subsubsection{Theoretical and Practical Implications}

This study revealed that it was not what category $\mathrm{C}$ taxpayers anecdotally cite as a major determinant factor for their grievance over their 2017 tax assessment, namely their income falling short of the amount they are assessed to pay in taxes. Instead, their perception of distributive justice and emotional attachment with the government stood as stimulators of intention to voluntarily pay taxes. In addition, the interactive effect of procedural and distributive justice on intention to pay taxes voluntarily was significant. Owing to the significant interactive role of procedural and distributive justice on intention to pay taxes voluntarily, this study contributes a noble finding to the tax compliance literature extending the interactive role of the two types of (i.e., procedural and distributive) justice that has extensively surfaced in the organization behavior studies (see e.g., Shapiro, 1991; Brockner et al., 1994; Brockner and Wiesenfeld, 1996; De Cremer, 2005; De Cremer et al., 2010). As to the knowledge of the author, this finding has never been documented in the tax compliance context by any prior study and is hence a new significant contribution.

This study also contributes to tax administration and tax policy design. One tax administration as well as 
policy implication of the study is that female taxpayers reported that they are more compliant with their tax obligations than their male counterparts, as a result of which enforcement efforts need to be geared toward male than female taxpayers. A second practical contribution of the study is that older respondents indicated that they have lesser intention to voluntarily pay their taxes than their younger counterparts, and this informs tax authorities and tax policy makers that more needs to be done to get the willingness of elder people to pay their taxes voluntarily. A third contribution is that perceived fair distribution of tax burdens and tax-funded benefits (i.e., distributive justice) and emotional attachment of taxpayers with the tax authorities are associated with high level of intention to voluntarily pay taxes.

A fourth and more pervasive contribution of this study is that tax authorities would be informed about the interactive effect of two justice components - procedural and distributive justice - in stimulating voluntary cooperation of citizens with authorities. Specifically, a perceived low level of distributive justice of the tax authority is shown to be buffered by a high rather than low procedural justice.

\subsubsection{Limitations and Future Research Direction}

As is the case with all research, this research is not free from limitations. The first limitation is that the data used in this study is self-reported data on a highly sensitive subject about which respondents are not believed to provide genuine answers. This is presumably because taxpayers are less likely to confess their tax evasion as they fear legal actions following their self-report (see, for instance, Torgler, 2008; Wenzel, 2002; Murphy, 2004). Hence, other controlled methods such as experimental method are recommended to replicate the results of this study. The second limitation is that data for the study was gathered through a one-time cross-sectional survey and hence it would not warrant causal claim between the study variables. Consequently, other research with a longitudinal or experimental design might warrant causal relationship between the variables. The third limitation is that the sample respondents in this study were not randomly selected and thus will not be representative any population. Random selection of respondents was not possible because tax authorities view taxpayers' information as highly confidential and the researcher had to resort to convenient sampling whereby any accessible category $\mathrm{C}$ taxpayers from the geographic areas specified for this research were included. Therefore, the results must be cautiously viewed in a way they are less likely to be generalized to any population outside the sampled respondents.

\section{Acknowledgements}

This research was financed by the Ethiopian Civil Service University.

\section{Appendix}

Below is a list of two of the measures used in this paper. All responses were on a Likert scale $(1=$ strongly disagree, 2 = disagree, $3=$ moderately disagree, $4=$ neither agree nor disagree, $5=$ moderately agree, $6=$ agree, 7 = strongly agree) .

Procedural Justice (Colquitt, 2001)

The following items refer to the procedures used to arrive at tax-related decisions.

1. I have been able to express my views and feelings during those procedures.

2. I have had influence over the (outcomes) arrived at by those procedures.

3. Those procedures have been applied consistently.

4. Those procedures have been free of bias.

5. Those procedures have been based on accurate information.

6. I have been able to appeal the (outcomes) arrived at by those procedures.

7. Those procedures have upheld ethical and moral standards.

Distributive Justice (Verboon and van Dijke, 2007)

1. The use I make of all kinds of social services reflects in a proper way the taxes I pay.

2. Regarding social services I get little return for my tax money; reverse coded.

3. Some groups in society benefit more from the tax system than I do; reverse coded.

4. I think it is not fair that some people pay less tax than me while they benefit equally from all amenities; reverse coded.

5. I find that I have to pay too much tax; reverse coded.

Intention to Voluntarily Pay Taxes (Kirchler and Wahl, 2010)

When I pay my taxes as required by the Ethiopian tax laws and regulations, I do so...

1. ... because to me it's obvious that this is what you do.

2. ... to support the state and other citizens.

3. ... because I like to contribute to everyone's good.

4. ... because for me it's the natural thing to do.

5. ... because I regard it as my duty as a citizen.

Affect-based Trust (McAllister, 1995)

1. The tax officials and I have a sharing relationship; we can both freely share our ideas, feelings, and hopes.

2. I can talk freely to these officials about difficulties I am having regarding tax and know that they will want 
to listen.

3. We would both feel a sense of loss if we could no longer work together.

4. If I shared my problems with these officials, I know they would respond constructively and caringly.

5. I would have to say that we have both made considerable emotional investments in our working relationship.

Cognition-based Trust (McAllister, 1995)

1. The tax officials approach their job with professionalism and dedication.

2. Given these officials' track record, I see no reason to doubt their competence and preparation for their job.

3. I can rely on these persons not to endanger my business by careless work.

4. Most taxpayers, even those who aren't close friends of these officials, trust and respect them as officials.

5. Other taxpayers I know who must interact with these officials consider them to be trustworthy.

6. If people knew more about these officials and their background, they would be more concerned and monitor their performance more closely.

\section{References}

Adams, J. S. (1965). Inequity in Social Exchange. In L. Berkowitz (Ed.), Advances in Experimental Social Psychology, 2, 267-299. New York: Academic Press.

Alm, J., Jackson, B. R., \& McKee, M. (1993). Fiscal exchange, collective decision institutions, and tax compliance. Journal of Economic Behavior \& Organization, 22(3), 285-303. doi:10.1016/0167-2681(93)90003-8

Bekana, D. M., Gobena, L. B., \& Yibrah, D. G. (2014). Evaluation of Ethiopian tax administration system: Emphasis on taxpayers' compliance. Journal of Business and Administrative Studies, 6(2), 46-75.

Bianchi, E. C., Brockner, J., van den Bos, K., Seifert, M., Moon, H., van Dijke, M., \& De Cremer, D. (2015). Trust in Decision-Making Authorities Dictates the Form of the Interactive Relationship Between Outcome Fairness and Procedural Fairness. Personality and Social Psychology Bulletin, 41(1), 19-34. doi: $10.1177 / 0146167214556237$

Bird, R. M., \& Zolt, E. M. (2008). Tax policy in emerging countries. Environment and Planning: Government and Policy, 26, 73-86. doi:10.1068/cav3

Braithwaite, V. (2003). Tax system integrity and compliance: The democratic management of the tax system. Taxing Democracy: Understanding Tax Avoidance and Tax Evasion, Ashgate Publication. 271-290.

Brockner, J. (2002). Making sense of procedural fairness: how high procedural fairness can reduce or heighten the influence of outcome favorability. Academic Management Review, 27, 58-76. doi: 10.5465/amr.2002.5922363

Brockner, J., Konovsky, M., Cooper-Schneider, R., Folger, R., Martin, C., and Bies, R. J. (1994). Interactive effects of procedural justice and outcome negativity on victims and survivors of job loss. Acad. Manage. J. 37, 397409. doi: $10.5465 / 256835$

Brockner, J., and Wiesenfeld, B. M. (1996). An integrative framework for explaining reactions to decisions: interactive effects of outcomes and procedures. Psychol. Bull. 120, 189-208. doi: 10.1037/00332909.120.2.189

Colquitt, J. A. (2001). On the dimensionality of organizational justice: a construct validation of a measure. Journal of Applied Psychology, 86(3), 386-400. doi:10.1037//0021-9010.86.3.386

De Cremer, D. (2005). Procedural and distributive justice effects moderated by organizational identification. Journal of Managerial Psychology 20(1): 4-13.

De Cremer, D., Brockner, J., Fishman, A., van Dijke, M., van Olffen, W., \& Mayer, D. M. (2010). When do procedural fairness and outcome fairness interact to influence employees' work attitudes and behaviors? The moderating effect of uncertainty. Journal of Applied Psychology, 95(2), 291-304. doi: 10.1037/a0017866

Doyle, E., Gallery, K., Coyle, M., \& Commissioners, I. R. (2009). Procedural Justice Principles and Tax Compliance in Ireland: A Preliminary Exploration in the Context of Reminder Letters. Journal of Finance and Management in Public Services, 8(1), 49-62.

Falkinger, J. (1995). Tax evasion, consumption of public goods and fairness. Journal of Economic Psychology, 16(1), 63-72. doi:10.1016/0167-4870(94)00038-c

Farrar, J. (2015). An empirical analysis of taxpayers fairness preferences from Canada's Taxpayer Bill of rights. Journal of Accounting and Taxation, 7(5), 71-79. doi:10.5897/JAT2015.0183

Farrar, J., and Thorne, L. (2012). The effect of outcome favorability and fairness on tax compliance, in Proceedings of the CAAA Annual Conference 2013, Montreal.

Fjeldstad, O.-H. (2001). Taxation, Coercion and Donors: Local Government Tax Enforcement in Tanzania. The Journal of Modern African Studies: A Quarterly Survey of Politics, Economics and Related Topics in Contemporary Africa, 39(02), 289-306. 
Fjeldstad, O.-H., Schulz-Herzenberg, C., \& Sjursen, I. H. (2012). Peoples' views of taxation in Africa: A review of research on determinants of tax compliance. ICTD Working Paper 8. Institute of Development Studies. Brighton, UK.

Fjeldstad, O.-H., \& Therkildsen, O. (2008). Mass taxation and state-society relations in East Africa. In O.-H. Fjeldstad, M. Moore, \& D. Braütigam (Eds.), Taxation and State-Building in Developing Countries: Capacity and Consent (pp. 114-134). Cambridge: Cambridge University Press.

Folger, R. (1986). Rethinking equity theory. In H. W. Bierhoff, R. L. Cohen \& J. Greenberg (Eds.), Justice In Social Relations, 145-162. New York: Plenum Press.

Gobena, L. B., \& van Dijke, M. (2016). Power, justice, and trust: A moderated mediation analysis of tax compliance among Ethiopian business owners. Journal of Economic Psychology, 52(2016), 24-37. doi:http://dx.doi.org/10.1016/j.joep.2015.11.004

Gobena, L. B., \& Van Dijke, M. (2017). Fear and caring: Procedural justice, trust, and collective identification as antecedents of voluntary tax compliance. Journal of Economic Psychology, 62, 1-16. doi:https://doi.org/10.1016/j.joep.2017.05.005

Hartner, M., Rechberger, S., Kirchler, E., \& Schabmann, A. (2008). Procedural fairness and tax compliance. Economic Analysis and Policy, 38(1), 137-152. doi: http://dx.doi.org/10.1016/S0313-5926(08)50010-5

Hayes, A. F. (2013). Introduction to mediation, moderation, and conditional process analysis: A regression-based approach: Guilford Press.

Jason, S., and Tyler, T. R. (2003). The role of procedural justice and legitimacy in shaping public support for policing. Law Soc. Rev. 37, 513-548. doi: 10.1177/1529100615617791

Jones, D. A., \& Skarlicki, D. P. (2013). How perceptions of fairness can change A dynamic model of organizational justice. Organizational Psychology Review, 3(2), 138-160. doi: 10.1177/2041386612461665

Kazemi, A. (2009). There is more to fairness in taxation than fair taxes: Introducing a multi-faceted fairness framework of taxation. S. Jern \& J. NE aslund (Eds.), Dynamics within and outside the lab, 147-158.

Kirchler, E., \& Wahl, I. (2010). Tax compliance inventory TAX-I: Designing an inventory for surveys of tax compliance. Journal of Economic Psychology, 31(3), 331-346. doi: 10.1016/j.joep.2010.01.002

Leary, M. R. (2012). Introduction to Behavioral Research Methods (6 ed.). Boston: Pearson Education, Inc.

Leder, S., Mannetti, L., Hölzl, E., \& Kirchler, E. (2010). Regulatory fit effects on perceived fiscal exchange and tax compliance. Journal of Socio-Economics, 39(2), 271-277. doi:10.1016/j.socec.2009.12.003

Leventhal, G. S. (1980). What Should be Done with Equity Theory? Washington, D.C.: Springer.

Lind, E. A. (2001). Fairness Heuristic Theory: Justice Judgments as Pivotal Cognitions in Organizational Relations. Advances in Organizational Justice, 56, 88.

Lind, E. A., \& Tyler, T. R. (1988). The social psychology of procedural justice. New York: Plenum Press.

Longoni, E., \& Gregorini, F. (2009). Inequality, Political Systems and Public Spending. Working Paper Dipartimento di Economia Politica, Università di Milano Bicocca; $n$. 159.

McAllister, D. J. (1995). Affect- and Cognition-Based Trust as Foundations for Interpersonal Cooperation in Organizations. The Academy of Management Journal, 38(1), 24-59. doi: 10.2307/256727

Moser, D. V., Evans, J. H., III, \& Kim, C. K. (1995). The Effects of Horizontal and Exchange Inequity on Tax Reporting Decisions. The Accounting Review, 70(4), 619-634.

Murphy, K. (2003). Procedural justice and tax compliance. Australian Journal of Social Issues, 38(3), 379-408.

Murphy, K. (2004). The role of trust in nurturing compliance: A study of accused tax avoiders. Law and Human Behavior, 28(2), 187-209. doi: 10.1023/B:LAHU.0000022322.94776.ca

Murphy, K., \& Tyler, T. (2008). Procedural Justice and Compliance Behaviour: The Mediating Role of Emotions. European Journal of Social Psychology, 38(4), 652-668. doi:10.1002/ejsp.502

Palil, M. R. (2010). Tax Knowledge and Tax Compliance Determinants in Self Assessment System in Malaysia. (PhD Dissertation), University of Birmingham, Birmingham.

Prichard, W. (2010). Taxation and State Building: Towards a Governance Focused Tax Reform Agenda. IDS Working Papers, 2010(341), 01-55. doi: 10.1111/j.2040-0209.2010.00341_1.x

Rablen, M. D. (2010). Tax evasion and exchange equity: A reference-dependent approach. Public Finance Review, 38(3), 282-305. doi:10.1177/1091142110367858

Saad, N. (2011). Fairness Perceptions and Compliance Behaviour: Taxpayers' Judgments in Self-Assessment Environments. (PhD Dissertation), University of Canterbury, Canterbury. Retrieved from http://hdl.handle.net/10092/5065

Seidikides, C., De Cremer, D., Hart, C. M., \& Brebels, L. (2010). Procedural Fairness Responses in the Context of Self-Uncertainty.

Shapiro, D. L. (1991). The Effects of Explanations on Negative Reactions to Deceit. Administrative Science Quarterly, 36(4), 614-630. doi: 10.2307/2393276

Tanzi, V. (2006). Fiscal policy: when theory collides with reality: Center for European Policy Studies.

Thibaut, J. W., and Walker, L. (1975). Procedural Justice: A Psychological Analysis. Hillsdale, NJ: Lawrence 
Erlbaum Associates.

Torgler, B. (2008). Causes and consequences of tax morale: An empirical investigation. Economic Analysis and Policy, 38(2).

Traxler, C. (2009). Voting over Taxes: The Case of Tax Evasion. Public Choice, 140(1/2), 43-58.

Tyler, T. R., and Blader, S. L. (2000). Cooperation in Groups: Procedural Justice, Social Identity, and Behavioral Engagement. Philadelphia, PA: Psychology Press.

Tyler, T. R. (2009). Procedural justice, identity and deference to the law: what shapes rule-following in a period of transition? Aust. J. Psychol. 61, 32-39. doi: 10.1080/00049530802607639

Van den Bos, K., Vermunt, \& Wilke. (1996). The Consistency Rule and the Voice Effect: The Influence of Expectations on Procedural Fairness Judgments and Performance. European Journal of Social Psychology, 26(3).

van Dijke, M., \& Verboon, P. (2010). Trust in Authorities as a Boundary Condition to Procedural Fairness Effects on Tax Compliance. Journal of Economic Psychology, 31(1), 80-91. doi:10.1016/j.joep.2009.10.005

Van Dijke, M., Gobena, L. B., \& Verboon, P. (2019). Make Me Want to Pay. A Three-Way Interaction Between Procedural Justice, Distributive Justice, and Power on Voluntary Tax Compliance. Frontiers in psychology, 10, 1632-1632. doi: 10.3389/fpsyg.2019.01632

Verboon, P., \& Goslinga, S. (2009). The role of fairness in tax compliance. Netherlands Journal of Psychology, 65(4), 136-145. doi:10.1007/bf03080136

Verboon, P., \& van Dijke, M. (2007). A self-interest analysis of justice and tax compliance: How distributive justice moderates the effect of outcome favorability. Journal of Economic Psychology, 28(6).

Wahl, I., Muehlbacher, S., \& Erich, K. (2010). The impact of voting on tax payments. Kyklos, 63(1).

Weick, K. E. (1995). Sensemaking in organizations. Thousand Oaks, CA: Sage.

Wenzel, M. (2002). The Impact of Outcome Orientation and Justice Concerns on Tax Compliance: The Role of Taxpayers' Identity. Journal of Applied Psychology, 87(4), 629-645. doi:10.1037//0021-9010.87.4.629

Wenzel, M. (2003). Tax Compliance and the Psychology of Justice: Mapping the Field. Taxing Democracy, 4170 . 